\title{
THE IMPACT of SARS - CoV-2 VIRUS ON CONSUMER PREFERENCES
}

\begin{abstract}
The SARS-CoV-2 virus appeared in the Chinese city of Wuhan, drastically changing consumer preferences ever since. Globalization and facilitated means of sharing information have had a considerable impact on consumer preferences. These preferences are ranked differently as a result of the unknown future of unfolding crisis. Specific changes in the business environment have caused intensive employment of crisis management and other comparable approaches in the problem-solving process in companies, which ensued as a result of the pandemic. The main purpose of this paper is to explain how consumers change their opinion about the importance of different goods and how companies may utilize these changes towards their own business objectives. The paper also shows how goods are classified according to different types of preferences. The final aim of this analysis is to contribute to a general understanding of how companies could change their business practices to create innovative products and establish better communication channels with their customers and other businesses.
\end{abstract}

Keywords: SARS-CoV-2, crisis situation, consumer preferences, innovation

\section{INTRODUCTION}

The social problem that is the starting point in this presentation is the pronounced globalization of the world, the vast flow of information via the Internet and greater movement of people as a basis for the spread of SARS-

\footnotetext{
${ }^{1}$ vtijana33@gmail.com
} 
CoV-2 virus, with subsequent changes in consumer preferences. The twentieth century is considered to be the period of emerging globalization, and nowadays it is stated that the process itself is completely finished. The development of information technologies has contributed to the further acceleration of this process due to the greater availability of information. With greater availability of information and greater connection of people via the Internet, there has been a faster exchange of data, goods, capital and the movement of people. However, with the appearance of the SARS-CoV-2 virus in the Chinese city of Wuhan and the rapid spread of information, there have been changes in the ranking of products and services, i.e. a sudden change in consumer preferences and in the use of products and services. New social circumstances worsen the situation in some economic activities, at the same time creating opportunities for a new way of doing business and for innovation that would respond to the crisis and expand market presence. In a large number of countries, borders have been closed, the movement of people has been restricted and the scale of many economic activities has been diminished or completely suspended, which has led to problems in the delivery of products. At the same time, the need for a large number of service activities has been reduced, due to an increase in the work-from-home model. All these new circumstances have led to a different ranking of products and services, i.e. a different evaluation of the contents of the consumer basket.

The subject of the paper is the impact of changes and information at the international and national level on the assessment of product value by consumers and the final effect this bears on the state of the economy. The research refers to the factors that affect the assessment of the value of products, the willingness of consumers to replace products or to give up the purchase of certain goods due to the existence of changes in income. The spread of the SARS-CoV-2 virus has changed the evaluation of goods and services by consumers. In addition to this factor, some of the key contributors to consumer perception are the media, institutions as well as individuals or groups that surround each consumer individually. Along with the external factors that have impact on consumer perception, their assessment is influenced by personal experience of the crisis situation, their previous experience, as well as personal motives for achieving some desired goal (such as striving to avoid virus transmission, helping people in their environment, etc.). As a consequence of changed consumer behavior, there is a change in market demand and negative impact on producers who produce goods for which consumers show less interest. The result is that producers must have the adequate skills and knowledge to apply crisis management and show a willingness to better adapt in the event of recurrence of similar crises. By considering the changes in consumer behavior in crisis situations, one can understand the extent of 
changes, the influencing factors and steps that companies should take to reduce the negative effects.

\section{GLOBALIZATION AND THE ORIGIN OF THE CRISIS}

Globalization is a process that began in the twentieth century as an idea that would contribute to faster and easier networking of national economies, greater flow of information, greater exchange of opinions, knowledge, experience, innovation and thus greater productivity. In addition, there is a significant contribution to the flow of finances, but also to increased competition among producers. On the other hand, greater connectivity leads to faster dissemination of information in crisis situations, which can make major changes in the goods market to the point of shortages of certain products in retail outlets. The outbreak of the SARS-CoV-2 virus, first recorded in the Chinese city of Wuhan, is an example of major changes in the evaluation of the usefulness of products by consumers and the emergence of imbalances in the market of goods and services. Such large changes can leave long-term negative consequences on the economy that would further spread to other countries to a greater or lesser extent depending, on the degree of their interdependence. If we add to this the reality of increased spending on health care, it is clear why there is much concern for the further development of the present crisis.

Despite these facts, a global crisis is a phenomenon that has occasionally occurred during different periods in the past. Throughout history, a large number of scientists and experts from various fields have dealt with various crisis situations and the consequences they would leave after their withdrawal from certain areas. According to the German-American economist Ote (2006, p. 36), the world was already extremely connected on a global level in the past: "It was between 1870 and 1914 that the global economic system existed. In these years, there was such a movement of goods and capital that encompassed the entire world, and people moved with great freedom between individual continents ". In addition, he expands his views on globalization and crisis by claiming: "But crises have always been born in an age of euphoria and optimism. When people begin to believe that the business cycle has finally been overcome (such as infectious diseases such as malaria or plague) sooner or later the circumstances will disprove them" (Ote, 2006, p. 29). From these statements, it can be argued that owing to globalization, there was a probability for various crises to break out in the past. Therefore, we can safely discuss new problems after the disappearance of a crisis, which in this case manifests itself as a health crisis. 
Crisis as a phenomenon can be interpreted as a change that interrupts the previous period of uninterrupted continuity and stability of the given cycle. It can have negative consequences for the whole society and the existing system. At the same time, it can create a condition for reaching new solutions and ideas that would tackle the negative effects, but at the same time there is a possibility that owing to them, the remaining positive elements from the previously built system will be annulled, thus creating new problems. Caslione and Kotler may be quoted as saying (Kotler, Caslione, 2009, p. 18): “Today's world of increased interconnectedness and interdependence means more risk for every company. Critical factors that increase business risk opportunities include: technological advances and the information revolution, destructive technologies and innovations, the rise of others, hyper-competition, private hedge funds, the environment, and consumer empowerment". However, in this paper, the goal is to show the change in consumer preferences, the factors that influenced the creation of these changes as well as the potential measures that companies should implement to reduce the negative effects on their own business activities.

\section{THE OUTBREAK OF SARS-COv-2}

From the moment when the SARS-CoV-2 virus was registered for the first time in the Chinese city of Wuhan, researchers from various scientific fields have started researching the causes and consequences that the virus would leave after the epidemic. Natural and medical sciences contribute to determining the cause of the virus, treatment of patients, preventive measures to prevent its occurrence, prevention of further spread and the potential consequences it brings. In contrast, the social sciences try to answer the questions related to the behavior of people in the period before, during and after the epidemic, as well as trying to reorganize the patterns of human obligations, the functioning of the economy and the public sector. Nowadays, it can be fully confirmed that new issues and problems have been opened regarding the functioning of the system of state institutions and economic participants, as well as the emergence of a new approach to thinking in order to better adapt one's business to the crisis and its consequences. Taking into account that World Health Organization has recommended greater distance between people in order to reduce the spread of the virus, many participants in economic activities organized work from home for work positions that do not need to be performed from offices or on-site. The governments of many countries have decided to close the borders to prevent the movement of people, and as a result of emergency measures, there has been a delay in the delivery of certain goods. Also, shopping malls, catering facilities, hotels were 
temporarily closed in some countries, and in the end, tourist arrangements were canceled. All the mentioned decisions of the competent institutions affected the reduction or complete suspension of earnings, with micro, small, medium enterprises and entrepreneurs being the most affected, which represent an important basis of economic activity in Serbia.

At the national level, in order to maintain economic activity throughout the crisis, assistance from the Government of the Republic of Serbia through the Program of economic measures is needed to reduce the negative effects caused by the SARS-CoV-2 virus pandemic and the Program of financial support to the SARS-CoV-2 crisis of the Development Fund of the Republic of Serbia is extremely important. In addition to the above measures of state institutions, businessmen were also offered credit lines by the European Bank for Reconstruction and Development (EBRD) and the European Investment Bank (EIB). European Bank for Reconstruction and Development credit lines would be placed through local branches of commercial banks. Alongside this great commitment of state institutions to help the economy as well as the additional efforts of foreign entities, consumer preferences changed during the pandemic and left visible consequences on various economic activities. Finally, we can say with certainty that at the global level, participants in the economic flows of different countries are more concerned with potential new crisis situations, but also with the possibilities for mitigating the consequences.

\section{CHANGED CONSUMER BEHAVIOUR}

With the appearance of the SARS-CoV-2 virus, the world media were dedicated to reporting on the situation in health care institutions, the lack of medical equipment, employees and patients who were in various stages of the disease. In addition, there was much information on ways of transmitting the virus, its presence in the general, regional and local population as well as ways to control it in the surrounding area (intensive disinfection of the area, increased hand hygiene, wearing protective masks). All of the aforementioned information significantly affects individuals through television, press, and Internet coverage. When the personal experiences of individuals who have encountered the virus are added to that, it resulted in a significant change in the preference for certain goods in the form of increased purchase of medicines and supplements, personal hygiene products and intensive purchase of space disinfectants.

The consumption of goods and use of services can be viewed from two angles of consumer perception. The first would refer to the increased consumption of certain goods due to the presence of the SARS-CoV-2 virus, while the second would refer to the change in the purchase of goods within the 
same industry. In the first case, we are talking about the increased purchase of goods that serve as a preventive measure due to the presence of SARS-CoV-2 virus and the closure of borders: space disinfectants, personal hygiene products and certain food items. In the second case, we are talking about changes within the same area, such as a reduction in the utilization of natural cleaning products in comparison to classic chemical products. In both cases, consumers' purchasing decisions are influenced by personal income, information about various products and the general impression of the current situation resulting from the outbreak.

Owing to a varying level of information in the crisis situation, consumers act differently, and some are selectively exposed to information depending on the level of interest in the market, stories circulating in their environment and the recommendations of the authorities. Before making a decision to buy a certain product, the consumer assesses the crisis situation in which the company currently finds itself, collects information about the product using different media, thinks about the availability and properties of brands and considers various expert advice (doctors, pharmacists, chemists). Due to the reduced availability of products used by the consumer due to border closures and distribution setbacks, the consumer opts to purchase products that he/she has not used before and adapts some of them to new needs, which gives them a new purpose or a new use. However, after a long period of daily exposure to information, one becomes accustomed to the changed social reality and general acceptance of the new way of functioning and different use of goods and services. The new circumstances experienced by the consumers are combined with experiences from previous periods of crisis situations in the form of shortages of goods in stores and sudden changes in prices, which leads to a different overall impression and thus results in a different motivation to buy.

With the outbreak of the SARS-CoV-2 virus, employers sent some employees on forced annual leave, some were given a decision to terminate their employment contract, while many have been receiving reduced salaries due to a reduced demand for some goods and services on the market. All the mentioned decisions of the employers have reduced or completely stopped the earnings of a large number of the workforce, and based on such moves of the management, the employees are forced to adjust their spending to the reduced financial possibilities. In a crisis situation and reduced economic expectations of most consumers, there is a changed expectation of individuals, with preference given to products that are attributed to a greater effect of use such as: food, chemicals and personal hygiene. On the other hand, consumers are less likely to buy products that have less of an effect during the virus epidemic: furniture, footwear, clothing, luxury products. The assessment of the usefulness of a product in a crisis situation depends on the attitudes formed by the consumer on the basis of personal evaluation and the influence of the 
environment. The influence of the environment that has an impact on the consumer is also important, which is manifested in the previous experiences of other individuals in the form of family and friends and the opinions of experts from various fields such as specialists in various fields of medicine and chemists. Due to exposure to a large influx of information from various sources and general instability in the market, the consumers may find themselves unable to properly assess the benefits of purchasing certain products. At the same time, retail chains and manufacturers can use such a situation as an opportunity to misrepresent their products through the media and thus increase sales of their products.

In a crisis situation, there is a possibility of misuse of fear among consumers for marketing purposes. The basis for manipulation can be found in the present fear among consumers regarding the prevalence of the virus, preventive measures, ways to combat it and the availability of products and services. In a situation whose further outcome is not known, it is necessary for the competent institutions to perform regular control of producers, retail chains and agencies in charge of marketing campaigns. In an atmosphere of fear and panic, manufacturers and retail chains have the opportunity to misrepresent the properties of products, exaggerating their importance and efficiency during the health crisis, leaving the consumer with inadequate information and misjudgment. In the general social crisis, the consumer is left in a state of complete subjective assessment of the credibility of information, the adequacy of the marketing campaign and personal willingness to pay for certain products at higher prices due to reduced supply in the market. In order to prevent price instability and abuse by producers and retail chains in the commodity market, the Government of the Republic of Serbia has adopted a Decree on limiting the level of prices and margins of basic foodstuffs and protective equipment 35 / 2020-17, 55 / 2020-4, 57 / 2020- 13, 67 / 2020-3, 75 / 2020-4 and thus reduced the fear and panic of further price increases due to the lack of certain items. In addition to the interest in price stability, consumers are also interested in the appropriate distribution of goods that would provide each individual with the necessary products on time. In the crisis period, distribution problems become noticeable due to additional health security measures at border crossings, lack of certain raw materials and packaging for final products due to reduced or suspended production in the countries from which the goods are delivered. All the problems that could arise could be used by individual producers to play a larger role in the market and thus suppress smaller producers who have smaller production capacities, weaker management and marketing budgets. However, an increasing number of consumers are interested in buying products online, giving smaller manufacturers a chance to distribute their goods to the end user while avoiding often unprofitable retail chains as places for end sales. 


\section{CHANGED CONSUMER PREFERENCES}

The emergence of the SARS-CoV-2 virus has led to the closure of borders, reduced movement of people, changes in the way we work and changes in income that have modified the preferences of products and services. Consumer preferences in the field of services have become more focused on the use of mobile devices, online shopping and greater use of the Internet as a communication channel. The purchase of products is based on the preference of consumer goods, drugs and supplements. Consumer preference in a crisis situation can be seen as a commitment to consume products and services that would respond to the health crisis, reduced income and availability of products and services. In a time of crisis, the consumer decides to buy products in larger quantities, thanks to which he/she would respond to the health crisis adequately and secure themselves for a longer period of time due to the problems on the product supply side. This situation is a consequence of not knowing the direction of the crisis, the duration and possible end results. In a crisis situation whose further course is unknown, the consumer completely renounces some products or uses less products and services that he/she previously consumed, paying less attention to the money spent in favor of needed consumer goods, and at the expense of other products and services (clothing, footwear, travel). In addition, there is a chance of increasing costs due to price increases which would create less space for consumption of other products and services. All this represents a possible problem for the budget constraint of consumers whose income has been reduced due to economic problems.

In the Excerpt from the methodology of creating the consumer basket (17th number 021-188, 31/05/2010) published by the Republic Bureau of Statistics in cooperation with the Ministry of Trade and Services, the classification of products that make up the consumer basket was conducted. However, the relationship between the products in the consumer basket has changed significantly due to new needs and desires, and this is in line with the adjustment in the new crisis situation. Greater representation of required products in one basket (disinfectants and personal hygiene, food products, medicines and supplements) compared to another basket in which such products are not well-represented, leads consumers to buy the first basket, taking into account the budget constraints. This situation represents the preference of one basket over another, and is denoted with the symbol $>(\mathrm{X}>$ Y). In case the consumer already has stocks of desired products to adequately respond to the crisis situation, he/she gives less importance to the existing differences in the basket, and thus becomes indifferent because the increase in stocks will not have the same utility effect during the crisis (X Y). In case the consumer has to make a decision between different consumer baskets that have appropriate contents in an unpredictable and unstable situation and have the 
properties of substitutes (alcohol - chlorine), the baskets are assessed as equally useful $(X \geq Y)$, i.e. there is no pronounced preference for one particular basket.

In order for the consumer to be able to evaluate consumer baskets, it is necessary that each of them contains products that would be useful in a crisis situation (personal hygiene and disinfection products, medicines and supplements, food with a longer shelf life - frozen products, flour, sugar, oil, salt). Based on this, the consumer would adequately rank the baskets in accordance with their own budget constraint (X1, X2) $\geq(\mathrm{Y} 1, \mathrm{Y} 2),(\mathrm{Y} 1, \mathrm{Y} 2) \geq$ $(\mathrm{X} 1, \mathrm{X} 2)$. In a crisis situation, it is advisable to be able to rank more than two consumer baskets in order to reduce the impact of possible abuse of producers and retail chains in the pricing policy. In this way, each consumer basket would be as good as the others, and thus the consumer would mitigate the impact of price differences on his/her budget constraint (X1, X2) $\geq(\mathrm{Y} 1, \mathrm{Y} 2)$, (Y1, Y2) $\geq(Z 1, Z 2)$, i.e. $(X 1, X 2) \geq(Z 1, Z 2)$. However, when there is a problem in the availability of products on the market due to closing borders, increasing demand and lack of raw materials and packaging, the consumer is exposed to a reduced choice of products and consumer baskets. In a crisis situation, the consumer is instructed to reduce the possibility of combining products in the consumer basket. At such moments, a consumer basket that meets the criteria for responding to a crisis $(\mathrm{X} 1, \mathrm{X} 2) \geq(\mathrm{X} 1, \mathrm{X} 2)$ is considered a good enough consumer basket.

Amid a crisis, there occurs a modified classification of products from the consumer's point of view, greatly changing the desirability of the product. Due to the lack of certain wanted products, the consumer is looking for substitutes that are most pronounced in the field of disinfectants in which this relationship is expressed as, for example: alcohol-chlorine. Also, the same situation was recorded in the food industry, with the purchase of certain products that ensure the consumer would be provided with essential goods in the event of a total lockdown. This group of products includes: yeast and soda - bicarbonate, oil and fat, butter and margarine. In a crisis situation created by a viral epidemic, consumers move around less, in order to avoid possible infection. The result is that consumers are not interested in buying business clothes and shoes, summer equipment, or luxury products. Also, the consumer is interested in buying products whose joint use achieves the aimed objective of use, which is most visible in the personal hygiene products and house cleaning. In addition to the mentioned categories, there are also indivisible goods for which the consumer has shown greater interest. This category includes forms of property located outside cities and municipalities, the use of which would additionally protect the consumer from possible contamination (facilities outside populated areas). In a crisis situation, the consumer is forced to combine products in the consumer basket in different ways. In case of lack of certain brands or types of products, the consumer replaces them with other products with the same effect 
or use. However, in addition to the fact that the consumer changes the contents of the consumer baskets, the appropriate choice makes the consumer indifferent in their assessment. At the same time, other options do not enter the spectrum of consumer interest, except for those baskets that represent the best choice but are not available to him/her due to the crisis. This situation leads to different rankings where the curves of indifference do not intersect and the best options are the baskets towards which the consumer is indifferent due to the changed offer on the market.

When the consumer does not attribute importance to a certain brand in a crisis situation, it is said that consumer becomes indifferent, which satisfies the weighted averages of all available baskets that contain the wanted products (average product values are preferred in relation to them). In a crisis, the consumer is ready to buy a larger quantity in order to create stocks of products due to the reduced supply on the market. In such a situation, due to a budget constraint, the consumer is often forced to reduce the purchase of another product in the consumer basket. The reduced quantity of the second product is expressed as $\Delta \mathrm{x} 1$ (buys E $\Delta \mathrm{x} 1$ of product 2) and at the same time the increased consumption of the more wanted product as $\Delta \mathrm{x} 2$ (buys $\Delta \mathrm{x} 2$ / E of product 1). The quotient of these two types of products represents the consumer's willingness to exchange a less preferred product for a more preferred product (the exchange rate is expressed as - E). In the changed social circumstances, which are marked by a reduced supply on the market, the marginal willingness to pay for more desirable products has been swayed in the direction of the commitment to allocate a larger amount of money to more useful products.

\section{IMPACT OF CHANGES ON MICRO, SMALL, AND MEDIUM ENTERPRISES AND ENTREPRENEURS}

Based on the presented method of product evaluation by consumers in a crisis health situation, it can be concluded that a large difference in the purchase of goods is noticeable. On the one hand, the choice of consumers in favor of consumer goods has changed, while on the other hand there has been a change in the method of purchase, i.e. an increase in ordering and payment via the Internet. Due to the increased rates of work from home, canceled cultural and art events and tourist visits, as well as reduced or completely canceled celebrations, the craft services sector, the tourist industry and the event organization sector have been severely affected during the pandemic. Consequently, demand in the fashion and luxury goods sectors has decreased. In addition to major changes in the direction of decreasing demand for certain products and services, it is noticeable that demand has shifted from shopping in traditional brick-and-mortar facilities to online commerce. In this way, a 
great chance is given for the placement of goods to organizations that have smaller budgets and are not able to allocate more money for more expensive classic marketing campaigns and distribution through traditional sales channels (retail chains, shopping malls and other more expensive locations in cities and municipalities).

Along with a more affordable way of conducting marketing campaigns and a different way of distributing products and services, economic entities have the opportunity to form associations in order to create innovative products and services adapted to new crisis situations that have arisen as a result of the virus. New problems created in this way may vary in different areas of business, which creates a chance for innovation from multiple sources. Utilizing such associations, economic entities would adapt to the changed consumer preferences better and motivate purchases from new customers and service users. In addition, businesses have the opportunity to adapt their existing products and services to the new crisis situation and thus retain existing consumers. All the mentioned chances are easier to achieve thanks to the increased trade via the Internet, which enables faster communication with existing and new consumers. However, the implementation of such plans requires a constant exchange of information with the consumer, which creates the possibility of misuse of data for marketing purposes and use by third market participants. Beside the risks involved in collecting consumer data and the new forms of cooperation among economic participants, innovations enable expansion into new markets and better adaptation to the changing demand. At the same time, conditions to hire new experts on a global level arise, which create a framework for transferring experiences and information from other markets. Lastly, innovation creates new opportunities for experts from the national arena, which results in new employment prospects and increases exports.

In the emerging health crisis that brings with it economic problems in the form of major changes on the supply and demand side, problems in cooperation with business partners and problems within the organizations themselves, it is important to make a plan for emerging out of the business crisis. It is first necessary to look at the overall picture of the market situation, which manifests itself in the form of difficult access to repro-material, and the problems with distribution in a situation of state emergency measures, as well as due to the sudden changes in the preferences of consumers and service users. Moreover, it is vital to continually change or adjust the strategy of reaching the targets in the market depending on the area of change when it comes to the supply and demand side. It is also important to connect key people in the company, exchange information among employees and be in contact with external data sources (business organizations, government institutions) in order to make adjustments in due time and create new alternatives. 


\section{CONCLUSION}

In periods when there is no sudden crisis escalating, a large number of economic entities have a business plan which they utilize to compare current operations with the ones set out in the plan. However, with sudden abrupt changes such as the emergence of the SARS-CoV-2 virus, businesses are forced to make changes to existing business plans. Based on the current market situation, it is necessary to reconsider the business environment, i.e. to redefine the subject and objectives of the business in order to meet the changed needs in the market (changed consumer preferences and opportunities in other industries). In order to achieve this, it is important to establish and maintain good communication and trust with partner organizations and to secure contact with new business associates in order to broadly define the goals that would be in the interest of all parties involved. This broad, joint approach ensures faster penetration on new markets, which reduces the negative effects on the business that results from the pandemic. When creating a new joint strategy, it is important that economic entities exchange information on the situation in the business environment in real time, gather experiences and opinions from the management of other economic organizations and maintain contact with state institutions. Continual communication with state bodies in charge of the economy creates an opportunity to access various business development programs such as: more favorable loans, innovation vouchers, innovation centers (faculties, institutes), education. On the other hand, economic policy makers should, in cooperation with the economy, recognize new opportunities for economic development and employment, and include them in future economic strategies.

\section{REZIME \\ UTICAJ VIRUSA SARS- CoV-2 NA PREFERENCIJE POROŠAČA}

Virus SARS-CoV-2 se pojavio u kineskom gradu Vuhanu i promenio preferencije potrošača. Globalizacija i lak način za širenje informacija imaju uticaj na kreiranje različitih mišljenja o preferencijama. Ove preferencije su rangirane na drugačiji način kao rezultat nepoznate budućnosti kretanja krizne situacije. Specifične promene u poslovnom okruženju izazvale su intenzivnije korišćenje kriznog menadžmenta $\mathrm{i}$ drugačiji pristup u procesu rešavanja problema u kompanijama a koje su nastale usled pojave virusa. Glavna svrha ovog rada je da objasni kako potrošači menjaju mišljenje o važnosti različitih dobara i kako kompanije mogu da iskoriste ove promene za sopstvene ciljeve. Krajnji cilj ove analize je da se doprinese razumevanju kako bi kompanije 
mogle da menjaju svoje poslovne prakse, kreiraju inovaitvne proizvode $\mathrm{i}$ osvare bolju komunikaciju sa kupcima i drugim poslovnim partnerima.

Ključne reči: SARS-CoV-2, krizna situacija, preferencije potrošača, inovacija

\section{REFERENCES}

1. Akerlof, Dž., Šiler, R., (2010) Životni duh, Sl. Glasnik, Beograd.

2. Atkinson, R. D., Ezell, S., (2014) Ekonomika inovacija, Mate, Zagreb.

3. Brenkert, Dž. Dž., (2011) Marketinška etika, Sl. Glasnik, Beograd.

4. Chapman, E., O’Neil., (2003)Vodstvo, Mate, Zagreb.

5. Collins, D., J., (2014) Strateško razmišljanje, Datastatus, Beograd.

6. Deakins, D., Freel M., (2012) Preduzetništvo i male firme, Datastatus, Beograd.

7. Debertin, D.L.,(2012)Applied Microeconomics, Lexington.

8. Gaus, Dž., (2012) O filozofiji, politici i ekonomiji, Sl. Glasnik, Beograd.

9. Kotler, P., Caslione, J., (2009) Kaotika, Mate, Zagreb.

10. Nikolić Z. S., (2010) Metodologija naučno istraživačkog rada, Fakultet za ekonomiju i inženjerski menadžment, Novi Sad.

11. Ote, M., (2009) Slom dolazi,Romanov, Banja Luka.

12. Orlović, S., (2019)Vodič za izborne kampanje, Sl. Glasnik, Beograd.

13. Ougustin, N, R., (2010) Upravljanje kriznim situacijama, Datastatus, Beograd.

14. Pyndick R.S., Rubinfeld D. L., (2005)Mikroekonomija, Mate, Zagreb.

15. Rainer, R,K., Turban, E., (2009) Informacioni sistemi,Datastatus, Beograd.

16. Rodžers, D. L., (2019)Vodič kroz digitalnu tranformaciju, Finesa, Beograd.

17. Sir, A. L., (2009) Kako da napravite biznis plan, Datastatus, Beograd.

18. Solomon, M., Bamossy, G., Askegaard, S., Hogg, M. K.,Consumer Behavior, A EuropeanPerspective, Prentice Hall.

19. Izvod iz metodologije izrade potrošačke korpe, Republički zavod za statistiku17 broj 021-188, 31.05.2010.

20. Odluka o ograničenju visine cena i marži osnovnih životnih namirnica i zaštitne opreme, 35/2020-17, 55/2020-4, 57/2020-13,67/2020-3, 75/20204 Sl. Glasnik RS, 52/19

21. Uredba o utvrđivanjuProgramapodrške privrednim subjektima za održavanje likvidnosti i obrtna sredstva u otežanim ekonomskim uslovima usled pandemije COVID-19 izazvane virusom SARS-CoV-2 54/2020-50, 57/2020-11Sl. Glasnik RS, br.54,57 
22. Uredba o uslovima i kriterijumima usklađenosti državne pomoći radi otklanjanja ozbiljnog poremećaja u privredi prouzrokovanog epidemijom zarazne bolesti COVID-19,54/2020-47, 126/2020-10Sl.GlasnikRS, br. $73 / 19$

23. Uredba o fiskalnim pogodnostima i direktnim davanjima privrednim subjektima u privatnom sektoru i novčanoj pomoći građanima u cilju ublažavanja ekonomskih posledica nastalih usled bolesti Covid-19: 54/2020-42,60/2020-4, Sl. Glasnik RS, br. 54,60

24. Uredba o postupkuinačinuodlaganjaplaćanjadugovanogporezaidoprinosa u ciljuublažavanjaekonomskihposledicanastalihusledbolesti COVID-19: 156/2020-6, Sl. Glasnik RS, br.156

25. Zakon o utvrđivanju garantne šeme kao mera podrške privredi za ublažavanje posledica pandemije bolesti COVID-19 izazvane virusom SARS-CoV-2: 153/2020-43, Sl. Glasnik RS, br. 153

26. https://pses.org.rs/statistika/Izvod_iz_metodologije_izrade_potrosacke_k orpe_2010.pdf

27. www.srbija.gov.rs/\#covid-19

28. www.who.int 